\title{
Structure and Modus Operandi of Code of Conduct Bureau and Public Complaints Commission in Enthroning Accountability in Governance: Nigeria Experience
}

DOI: https://doi.org/10.47175/rissj.v1i2.48

\section{| Alao Olaleke Michael |}

Director of Corporate Affairs, Centre for Convention on Democratic Integrity, Nigeria.

olaleke.alao@ccdiltd.org, alaoolaleke@gmail.com

\begin{abstract}
Laden with corruption, fear, and lack of job security, politicization reigns supreme; one would expect nothing short of low or poor performance of the accountability institutions in Nigeria. There have been lots of scholarly works on accountability, accountability institutions, administration and performance of one accountability institution or the other. It was revealed that majority of the studies examined the activities or performance of these accountability institutions. Most of the scholars that wrote on accountability institutions in Nigeria picked one institution at a time and more often than not, limit their study to limitations, challenges and impediments of performance; and/or at best bring out impediments of delivery of service. Some of the foreign scholars' writings and works conformed to the peculiarities of their environment which is different from what exists in Nigeria of today. What they wrote did not foresee the influence of politics on administration and did not put peculiarity of Nigeria into consideration. Issues like above the law syndrome, sacred cows, godfatherism, nepotism, favouritism, etc were not considered. This study in its peculiar form, afforded the staff of Public Complaints Commission and Code of Conduct Bureau the opportunity for self-assessment and self auditing; they were bulk of the respondents for both the questionnaire administration and interview. Accountability institutions in Nigeria have been alleged of not performing up to expectation or not performing at all by the public. It is against this background that this study seeks to assess the structure and modus operandi of the Code of Conduct Bureau and Public Complaints Commission in enthroning accountability in Governance. The study found out from the available information collected through the administration of questionnaire and conduct of in-depth interview that the awareness of Public Complaints Commission (PCC) and Code of Conduct Bureau $(C C B)$ is not in any way in-doubt amongst the elites in the country; the structure are perfect enough for the purpose for which it is set; there is cordial relationship between the superior and the subordinate; and there is room for free flow of information in the institutions.

KEYWORDS

Accountability; governance; performance; accountability institutions; public institutions
\end{abstract}

\section{INTRODUCTION}

Public institution refers to any organized establishment owned by the public; backed by law or public authority and equipped with facilities needed for such work. It is financed through public funds and controlled by the State. It is a legal entity and a juristic person. It 
sometimes referred to as the state-owned institution or public organization, which is an integral part of the state that deals with the production, ownership, sales, provision, delivery and allocation of goods and services by and for the government or its citizenry whether at national, regional or local level. In general terms, public institutions consist of government and all public-owned, controlled or funded agencies, enterprises and other entities that deliver public programmes, goods or services to the society as a whole (Louise, Ruth \& Diane, 2012)

Public institutions can generally be categorized into at least three types. First, is the core government, which consists of the governing body with a defined territorial authority. This includes all departments, ministries or branches of the government that are integral parts of the structure, and are accountable to and report directly to the central authority (legislature, cabinet or executive head). There are also agencies consisting of public organizations that are clearly part of the government and deliver public programs, goods, or services, but that exist as separate organization in their own right possibly as legal entities. They operate with a partial degree of operational independence. These agencies are often but not necessarily, headed by a board of directors, commission, or other appointed body. The third type of organization within the public sector is the public enterprises. They are agencies that deliver public programs, goods or services, but operate independently of government and often have their own source of revenue in addition to direct public funding. They may compete in private markets and make profits, however, in most cases the government is the major shareholder, and these enterprises partly follow the acts and regulations that govern the core government (The Institute of Internal Auditors, 2011).

In the report of the Political Bureau in 1986, it was observed that corruption and indiscipline were the bane of political development in Nigeria. It was then recommended that the existing machineries for monitoring the actions and behavior of public officers be strengthened to ensure conformity with the standards of public morality and accountability (Political Bureau, 1986). As a result, Code of Conduct Bureau and Code of Conduct Tribunal were established in accordance with the provisions in 1979 constitution to administer assets declaration and investigate Complaints of breaches of the code and adjudicate on the cases sent by the Bureau respectively (Code of Conduct Bureau, 2013).

The Public Complaints Commission (PCC) is an institution of the Federal Government of Nigeria established to shield the employees from oppression and maltreatment by their employers and other individuals. It is an independent organization established by the Federal Government of Nigeria in 1975 through Decree No. 31 of 1975, amended by Decree 21 of 1979, now Cap 377 Laws of the Federation of Nigeria 1990 and revalidated in Section 315(5) of 1999 Constitution (Constitution of the Federal Republic of Nigeria, 1999). The Commission was put in place to make available feasible alternative for Nigerians or its residents. It is an avenue to seek redress against administrative injustice arising from bureaucratic errors, omissions or abuse by official of governments or limited liability companies in the country. It is also to improve public administration generally by pointing out weaknesses observed in the laws, procedures, practices, rules, regulations and standards of behaviors of officials (Public Complaints Commission, 2012).

Conceptually, governance is about the rule, rulers and the ruled. One might then argue that governance is the process by which authority is conferred on rulers, by which they make the rules, and by which those rules are enforced and modified. Moreover, understanding governance requires an identification of the rulers and rules, as well as the various processes by which they are selected, defined, and linked together and the society generally. 
The act of governance relates to decision that define expectations, grant power, or verify performance. It consists of either a separate process or part of decision-making or leadership processes. In the World Bank's Poverty Reduction Strategy Papers (PRSP) Handbook, governance is seen as" the way power is exercised through a country's economic, political and social institutions." However, what obtains in Nigeria is that most of these institutions are perceived to have been turned to a toothless bull dog; they are being suppressed by the power-that-be. There is no more confidence in the government, and political participation is threatened.

It is based on this background that the study picked up interest in assessing the activities and performance of accountability institutions in Nigeria with special focus on the two selected public institutions, viz. Code of Conduct Bureau (CCB) and Public Complaints Commission (PCC) with the view to assessing their impact on accountability in governance in Nigeria.

\section{Hypothesis}

Ho: The activities and performance of the institutions do not have significant effect on accountability in governance in the period under study in Nigeria.

\section{REVIEW OF LITERATURE}

\section{Financial Management and Accountability}

Financial management is concerned with the planning, organizing, procurement and utilization of government financial resources as well as the formulation of appropriate policies in order to achieve the aspiration of members, the society. Premchand (1999) sees public financial management as the link between the community's aspirations with resources, and the present with future. It lies at the very heart of the operations and fiscal policy of government.

According to Burkead quoted in Ola and Effiong (1999:229), financial accountability means legal liability - the establishment of the pattern of control over the receipts and expenditures that permits a determination either by the executive or by the legislature (or both) that public monies have been used for public purposes. It is concerned with the establishment of pattern control over receipt and expenditure of public funds. Financial accountability is the justification of estimates, the superintendence of the use of appropriated funds, the devices for timing the rate of expenditure and the auditing of accounts

The challenges faced by public institutions among others are: unwillingness of the public to provide information by way of petitions, whistle blowing as well as the problems of inadequate manpower. Ojiakor (2009) argues that the factors and forces which militate against accountability in Nigeria include ethnicity and tribalism, corruption, religious dichotomy and military culture.

There are eight public accountability institutions under the presidency in Nigeria, namely: Code of Conduct Bureau (CCB); Economic and Financial Crimes Commission (EFCC); Federal Character Commission (FCC); National Human Rights Commission (NHRC); Public Accounts Commission (PAC); Public Complaints Commission (PCC); Utility Charges Commission (UCC); and Independent Corrupt Practices Commission (ICPC). But for the purpose of this study, attention will be placed on two of these accountability institutions which are CCB and PCC. 


\section{Vision and Mission of Code of Conduct Bureau}

The visions of Code of Conduct Bureau are honesty, transparency and accountability in public office while the mission statement is to eradicate corrupt practices and ensure compliance with the code of conduct for public officers

\section{Mode of Operation of Code of Conduct Bureau}

The modus operandi of Conduct Bureau in Nigeria is as follows:

\section{Assets Declaration Function of $C C B$}

The Bureau have succeeded in creating awareness among public officers on the constitutional provisions of assets declaration, while those who default are sent to the Code of Conduct Tribunal (a twin of the CCB - adjudicates on the cases sent to it by the CCB). The Bureau, for logistic reasons attach the requirement to declare as it found convenient. Level grade 7 and above officers are requested to declare their assets, with a lot of enlightenment so as to get the desired results. The Bureau goes ahead to confirm the claims by the declarants, this involves a lot of resources and logistics which are insufficient in the first place. Not only is the Bureau faced with the aforementioned, but it is also faced with the development of skilled personnel in verification, investigation and also the management of effective usage of Information Technology. (Code of Conduct Bureau Handbook, 2013)

\section{Investigation and Monitoring Function of $C C B$}

Complaints are received from the members of the public of breaches of the code of conduct by public officers through the departments of investigations and monitoring. This ranges from indiscipline, corruption, unethical conduct in government affairs, lack of accountability, abuse of office etc. Investigation is a more recent power confined on the Bureau. (Code of Conduct Bureau Handbook, 2013)

\section{Public Enlightenment, Education and Advisory Services Function of CCB}

In order not to fall ignorantly into the long arms of the law, the educational and advisory services department in the Bureau organizes workshops, conferences, public forum, advertisements through electronic and print media. For public enlightenment, there is the production and distribution of public handbooks and posters. (Code of Conduct Bureau Handbook, 2013)

\section{Aims and Objectives of the Code of Conduct Bureau}

The Bureau was to establish and maintain a high standard of morality in the conduct of government business and to ensure that the actions and behaviour of public officers conform to the highest standards of public morality and accountability; receive assets declarations by public officers in accordance with the provisions of the Act; examine the assets declaration and ensure that they comply with the requirements of this Act and of any law for the time being in force; take and retain custody of such assets declarations; and receive Complaints about non-compliance with or breach of this Act and where the Bureau considers it necessary to do so, refer such Complaints to the Code of Conduct Tribunal (CCT). (Code of Conduct Bureau Handbook, 2013)

\section{Mode of Operation of PCC}

The Public Complaints Commission is a body setup to check administrative excesses (nonadherence to procedures, policies or violation of Law). It is constitutionally empowered to 
handle Complaints lodged by aggrieved citizens or residents in Nigeria. The Commission provides impartial investigation on behalf of the citizen/residents who feels they have suffered injustice through the actions or in actions of Federal, States, Local Government and companies incorporated in Nigeria. (Public Complaints Commission, 2012). The Commission has the following responsibility:

Investigate and Conduct Researches in MDAs, Companies and Officials of these Bodies The power to investigate is vested on the Chief Commissioner / Commissioners to either on his own initiate a complaint based on his findings or following Complaints lodged before him by persons or any administrative action.

\section{Mandate to have Access to all Information}

The Commission has the statutory power to request for documents from any institution or company that is a subject of Complaints or investigation and also access to request for any individual with knowledge of the issue.

\section{Mandate to make Public Reports}

It is one of the mandates of the Commission to make public reports of its investigations and recommendations. This can also be forwarded to the supervisory bodies such as the National Assembly.

\section{Mandate on Interpretation of Policy and Advice to Government and Companies}

The Commission being the watchdog of administration in its act has the mandate to interpret government policies and advice thereon. In a situation where the citizen misinterpretes the government or a company policy and procedure, it is part of the mandate of the Commission to clarify the policy to the individual or make the agency or company clarify or change its policy. These are some of the reasons why the Commission is being established to strengthen democracy through good administration which leads to good governance of the society.

\section{Mandate to Investigate Administrative Procedures of any Court of Law in Nigeria}

Although one of the limitations of the Commission is not to entertain any case before any court of law or case pending before any court of law in Nigeria. But that does not mean that the Commission hands off completely, it must be pointed out here that the Commission, being the watchdog can witness the proceedings of such a case and if the Commission notice any form of injustice as a result of breach or violation of administrative procedures of the court, the Commission has the power to investigation and make necessary recommendation and submit its report to the authority in charge.

\section{Aims and objectives of the Public Complaints Commission (PCC)}

The Ombudsman aims at promoting social justice for the individual citizen. It is also to provide a viable option for Nigerians or any resident of Nigeria seeking redress against injustice arising from administrative bureaucratic errors, omission or abuse by officials of government or Limited Liability Companies in Nigeria. The Ombudsman has the role of improving public administration in general, by pointing out weaknesses observed in the Laws, procedures, practices, rules and regulations and standard behavior of officials. (Public Complaints Commission, 2012)

Social justice is regarded as important desideratum of society for without it, society will degenerate to anarchy. The arguments for it are self obvious. Human beings, as observed 
by Doyal and Gough (1991) can be seriously harmed by alterable social circumstance, which can give rise to profound suffering, such alterable social circumstance could be the lack of respect for the rule of law, lack of respect for human right, and the likes. In our basic humanity, we have the same capacity to be harmed or flourish by this alterable circumstance. It is therefore unjust to favor one individual or group to the detriment of others when it comes to confronting the social circumstances that will either harm or enhance the lives of human beings.

Social justice therefore has its foundation on the basic of social equality. All human beings have the same prospects for self fulfillment and self actualization. It is therefore wrong to discriminate against anybody on the basis of any socially or biologically conceived variables. Unfortunately, today in our society, there are many such variables that make discrimination so rampant. The rich and the powerful treat the weak and the poor as less than human. Employers disregard labour law when it comes to dealing with their employees, government itself through its various agencies is a major violator of the rights of people.

Social justice is flourishing when people have equal access to both economic and political rights. This means that there should be equitable distribution of both economic resources and political power in the country that has given rise to the feeling of marginalization by many people and communities in the country. Government statutory human rights bodies have the added responsibility of ensuring that victims of human rights abuse are compensated. Since human rights violation come to such bodies as claims, they must have the capacity to investigate such claims and verify their veracity or otherwise.

PCC delivers a high quality Complaints handling service, which considers and determines Complaints thoroughly but proportionately and conveys decisions clearly. It also uses the knowledge gained from previous investigations to contribute to improved public service delivery and to inform public policy. It is set to analyse and improve the efficiency and effectiveness of government, business processes and support functions, to further demonstrate transparency and ensure the best use of the public money.

\section{Importance of Accountability in Governance}

According to Staffan (2009), accountability is a central concept in comparative politics. Yet its growing popularity in a number of applied fields, including development policy, has resulted in a dilution of its content and introduced an undesirable semantic confusion. Olowu (2002) canvasses the following reasons why accountability is important in governance. He pointed out that "accountability is necessary for the efficient functioning of all organizations, especially the public sector in democratically governed states. Accountability structures in the public sector are surrogates for market forces in non market situations helping to reflect the preferences of the public as citizens and consumers in the public domain. It also serves as a quality control device by ensuring that those who hold public trust account for the trust to the citizens, and it is expected to reinforce the superiority of the public will over private interests especially in the provision and delivery of services to the public. Accountability is one of the five norms of good governance, the rest are efficiency, transparency, rule of law, and legitimacy." Interest in public accountability is provoked by the necessity to curb waste incidented by inefficient use of public wealth and conspiracy between the top bureaucratic and political class in rentseeking and various corrupt practices. The need for efficient management of the paltry wealth in the face of mounting prospect from the general public for service delivery calls for apposite accountability in the public sector. 
Ashaolu, Oyesanmi, Oladele \& Oladoyin (2005) explain accountability in the financial institutions through the theory of Agency according to Adesola (2001):

... the person who holds or manages a given amount of resources for the benefit of another person is an agent. As an agent, he must operate according to the mandate given to him and he must perform to the satisfaction of those who are to benefit from his achievement. The managers of a business enterprise are agents to the business owners as well as those who are to benefit from the activities of the business, including the society at large. At the end of each period of operation, the managers will render account of stewardship for the information of those who may be interested in the operation of the business.

They concluded that "with the provision of hierarchy, the bureaucracy in every financial institution provides for an accountable structure. Every person in the system has a place in the hierarchy, which facilitates accountable service". This is applicable to public sectors. From existing literatures, it can be deduced that accountability in governance is to assess the continuing efficacies of public officials or bodies; guarantee that the public officials and/or bodies are performing to their optimal potentials; providing importance for funds in the provision of public services; implanting confidence in the government; and being proactive to the public they are preordained to serve.

\section{Why is Accountability Important to Governance?}

Governance relates to processes of interaction and decision making among the actors involved in a collective problem that lead to the creation, reinforcement, or reproduction of social norms and institution. It is the rule of political system to solve conflicts between two actors and adopt decision. It is the proper functioning of institutions and their acceptance by the public to invoke the efficacy of government and the achievement of consensus by democratic participation.

Participatory Governance is the involvement of citizens in the process of governance with the state to deepen democratic engagement. This allows citizens to play a more direct role in public decision-making or at least engage more deeply with political issues. Governmental officials should be responsive to this kind of engagement.

Evaluating the ongoing effectiveness of public officials or public bodies, ensure that they are performing to their full potential, providing value of money in the provision of public services, instilling confidence in the government and being responsive to the community they are meant to be serving sums up to mean accountability. Sutcliffe (2002) suggests that "the relationship between good governance, fiscal transparency and better economic outcomes is increasingly acknowledged. Holding governments and their agencies accountable is a key element to good governance in the public sector."

\section{Empirical Review}

Onuorah \& Appah (2012) in their work, "Accountability and Public Sector Financial Management in Nigeria", found out that "the level of accountability is very poor in Nigeria because the attributes of accessibility, comprehensiveness, relevance, quality, reliability and timely disclosure of economic, social and political information about government activities are completely non available or partially available for the citizens to assess the performance of public officers mostly the political office holders". They therefore recommended that "among others, for accountability to be successful in the management of public funds in Nigeria, there must be a reduction in the level of corruption, improving public sector accounting and auditing standards, legislators as champions of accountability 
and restructure the public account committees" They concluded that "accountability is a central concept for governance; it requires that those who hold positions of public trust should account for their performance to the public or their duly elected representatives; and therefore implies that decision makers are monitored by, and are responsible to the people of the country. Also, in respect of public financial management, there are several mechanisms through which accountability is enforced such as the Auditor General, Public Account Committee, and the Ombudsman. These accountability mechanisms must be strengthened to reduce the level of corruption in the country.

Writing on the importance of accountability in the public sector, Appah (2010) poises that the number and monetary value of public sector activities has increased substantially. This increase in activities has brought with it an increased demand for accountability of public officers who manage these activities of the public. He further strengthened his argument by referring to cases of fraud that is prevalent in the Nigerian Public Sector that every segment of the public service, could seem to be involved in one way or the other in some of these nasty acts. In line with this argument, Bello (2001) discovers that there is near total absence of the notion and ethics of accountability in the conduct of public affairs in the country.

Olowu (2002) canvasses the following reasons in response to the importance of public accountability in the public sector: Accountability is necessary for the efficient functioning of all organizations, especially the public sector in democratically governed states; its structures in the public sector are surrogates for market forces in non market situations helping to reflect the preferences of the public as citizens and consumers in the public domain. It also serves as a quality control device by ensuring that those who hold public trust account for the trust to the citizens, and it is expected to reinforce the superiority of the public will over private interests especially in the provision and delivery of services to the public. Accountability is closely linked to the enjoyment of democratic life and democratic governance supposedly implies the supremacy of citizens in the governing process. To him, accountability is one of the five norms of good governance, the rest are efficiency; transparency, rule of law, and legitimacy. He therefore suggested that interest in public sector accountability is motivated by the need to curb waste occasioned by inefficient use of public resources and collusion between the top bureaucratic and political class in rent-seeking and sundry corrupt practices; the need for efficient management of the meagre resources in the face of rising expectations from the populace for service delivery calls for proper accountability in the public sector; and the increasing role of multi-lateral financial institutions, donors and actors through aid giving, technical and other forms of official assistance have increased the demand for accountability in order to improve governance and galvanise development.

Ibietan (2012) opines that corruption is a global issue, but it varies in intensity, sophistication and forms from country to country. The deduction or inference from extant literature, public commentaries, analyses, media (print and broadcast) including social networks seem to suggest that corruption is the largest industry with many practitioners in Nigeria. This has a lot of implications for development generally in the country. It is therefore not surprising that Adegbite (2009:33) averts that "...where there is no accountability, development will inevitably be stunted." He further corroborated that "In human history, no nation ever prospers with perverse values. In fact, no nation can prosper where personal will supplants the general will, where established procedures are observed in the breach, where governance is for self- enrichment rather than public service. Where there exists a yawning gap between leadership and stewardship... Virtuous societies are 
built by leaders who are accountable to the led and are driven by the altruistic desire to improve the lot of the highest number of the people".

Ogbuke and Enojo (2007:63) building on the works of Hornby (2001) see "corruption as a dishonest illegal behaviour", especially of people in authority or the act of making somebody change from moral to immoral standards of behaviour." This view adds an ethical /behavioural dimension to this discourse, and it suggests that unless sound moral principles anchored on enduring cultural values and practices are imbibed, the anti-graft campaign could amount to chasing shadows, especially in a country like Nigeria. These authors asserted unequivocally that "top level corruption is often controlled by hidden networks and represents the sum of various levels and types of irregular behaviour including abuse of power, conflict of interest, extortion, tribalism, nepotism or fraud". In corroborating this ethical angle to the conceptualization of corruption, Ifesinachi (2004:79) captures it "as all those behavioural orientations that impinge on and necessarily vitiates and destroys rules and basis of public and political conduct". He linked corruption in political and public life to "natural human factors of greed and ambition for socialpsychological, economic and political power". Poverty and serious economic hardships are often added as part of the motivations for corruption in Nigeria. This argument may be tenable for petty corruption as against grand corruption in public office. Petty or survival corruption according to Onwuka, Okoh and Eme (2009:119) "is practiced by civil servants, who may be grossly, underpaid and depend on small rents from the public to feed their families and pay school fees." Grand corruption which translates to kleptomania occurs among "high public officials and it often involves large sums of money". In whatever form corruption manifests, empirical studies have shown that it impinges on national development efforts as epitomised in the link between higher levels of corruption and lower investment and economic growth (Mamro in Ogbuke and Enojo, 2007:63).

In operationalising high-level or grand corruption, Kolade (2001:78) sees it "as the abuse of an influential position for private gain and... as the exploitation of a system for securing unmerited advantage". The first part of the definition according to him relates to holders of influential positions (in public office, bureaucracy and private sector) who have access to national economic resources in their vantage positions as custodians and stewards of these resources. The second part relates to people who lobby such office holders for access to preferential or undue advantage. He referred to both groups as agents of corruption. It is obvious from the allocative inefficiency and distributional inequities in Nigeria's public life, that access to public office confers enormous power on those saddled with political and economic management and it takes unusual /uncommon discipline to resist the urge or "temptation for corruption" in the words of Shinkafi in Idemudia (2008:513).

According to Awopeju \& Oyewole (2011) in their research, "An Assessment of the Cases of Ombudsman (PCC) as a Tool of Accountability in Ondo State, Nigeria, postulates that "ombudsman constitutes the 'ears' of the people. It is the 'ears' of the people because it serves as a mechanism of addressing injustice in a polity". They analyzed the cases disposed and cases under investigation (cases indisposed) of the Public Complaints Commission (PCC) in Ondo state, Nigeria, from the period of 2004-2009. The study showed that the PCC in Ondo state is not effective despite the number of cases brought to it yearly. The paper also revealed that there is no significant relationship between the cases disposed and cases indisposed within the period stated. It was also observed that government intervenes in the affairs of the commission to some extent; therefore PCC is not totally independent, as government control cannot be glossed over. The paper 
recommended that the PCC in Ondo state should draw up improvement in the cases disposed and indisposed.

Kabuoh \& Oyediran (2012) in Effectiveness of Public Complaints Commission on Labour Force: A Case Study of Nigeria Public Complaints Commission, conceptualizes the Public Complaints Commission (PCC) as "a parastatal of the Federal Government of Nigeria set up to defend the Nigerian worker from oppression and maltreatment by employers of Labour and individuals". They go further to affirm that "in the European Countries where the idea started, it is known as the Ombudsman. The Nigerian version of the Ombudsman actually started operation about thirty-four (34) years ago". The findings of the survey gave a positive impact of the activities of the commission on Labour force so far. It also showed that the commission still needs some serious proactive measures for greater percentage of the Labour force in Nigeria to be aware of its existence, because awareness is really at lower ebb. The study then recommended digitalization of operations to enable branch connectivity and enhances monitoring and easy dissemination of information within and outside the commission. Periodic enlightenment and education on PCC activities and available opportunities was also recommended for the staff of various establishments.

\section{Theoretical Framework}

The theoretical framework deemed appropriate for this study is the three perspectives of Bovens on accountability institutions in 2005. The three theoretical perspectives are highlighted as the raison d'être behind public accountability and assessment of accountability affairs (Boven, 2005) viz: democratic, constitutional and cybernetic perspectives. Out of these three perspectives, democratic and constitutional are considered useful for this study.

\section{Democratic perspective}

states that popular sovereignty takes into account democratic power to re-call or call to account political public office holders (March \& Olson, 1995; Mulgan, 2003). This approach inched on the tenets of Rousseau and Weber's principal-agent model. That at the end of a tenure the citizens pass judgement on the government and register their pleasure or displeasure of the government through their votes. Przeworski, Stokes \& Manin stated that "public accountability is an essential condition for the democratic process, as it provides the people's representation and the voters with the information needed for judging the propriety and effectiveness of the conduct of the government (Przeworski, Stokes \& Manin, 1999). This perspective is considered appropriate in Nigeria in the sense that Nigerians, most especially the elites and semi-literates are conscious of what is happening around them and with the use of social media, disseminate information and thereby exposing the government. This aggregates to form their decision during elections. Although, the danger is that even mis-information travels through the same channel. The influence of political parties on the press and social media has not been determined. This was the major play-out during the last general election in Nigeria.

\section{Constitutional Perspective}

is targeted at prevention of corruption and abuse of power. It is inched on the liberal tradition of Locke, Montesquien and O'Donnell. This perspective is geared toward prevention of tyranny, clientelism, patrimonialism, absolutism, arbitrary exercise of power and insolence on the part of the executive and its partner (civil service). Good governance arises from a dynamic equilibrium between the various powers of the state (Fisher, 2004). 
The constitutional perspective is a justification for the establishment of accountability institutions. The reason for the establishment of these institutions is the noticeable highhandedness of the political office holders and the civil service. If they are not put on check, the essence of public institutions would be defeated.

\section{RESEARCH METHODS}

In order to achieve the set objectives within the time frame, the research was carried out at the national headquarters of the two selected institutions. The reason for choosing these two institutions was occasioned by their uniqueness and responsibility of fighting corruption and inquiring into misconduct and abuse of public offices. All the states head office report to the headquarters and there is a replica of all the departments and units in the headquarters at the state level. Each department at the state level report as appropriate to the headquarters, hence, data from the headquarters provided information for this study.

In carrying out this study, sources of data collection that was adopted were primary and secondary. The research method was a descriptive study that adopted a cross-sectional survey design on the variables: governance, structure and modus operandi of the selected public accountability institutions. Copies of questionnaire were administered on 104 members of staff at the headquarters of the Public Complaints Commission using stratified random sampling technique across the three departments in the institution; and 19 members of the eight committees in the headquarters of Code of Conduct Bureau were also selected using random sampling technique. This distribution accounted for $50 \%$ of population in the two institutions.

To complement the data generated through questionnaire, interviews were conducted on 35 respondents, which were selected thus: three officials in the director cadre of the three Departments in Public Complaints Commission; Chairmen (or his/her representative) of the eight committees in Code of Conduct Bureau; 20 public servants (in active service or retired) were selected using simple random sampling technique; and four randomly selected officials of any Ministries, Departments and Agencies (MDA's) that have sought the services of Public Complaints Commission. Descriptive and inferential statistics were used to analyze the data obtained from the field. The research hypothesis was tested with the use of Simple Regression Analysis. The co-efficient was adopted in order to draw inference and to substantiate the findings of the study. Majority of the respondents really cooperated and completed the questionnaire; moreover, data obtained from the personal interview were qualitatively analyzed.

\section{RESULT AND DISCUSSION}

\section{The Structure and Mode of Operation of the Selected Accountability Institutions in Nigeria}

Distribution of the questionnaire assisted the researcher to collect useful information in the field of the research study; in this case, copies of questionnaire were administered on respondents and interview was also conducted as to whether the arrangement and style of operation of the PCC and CCB are effective and cordial.

From table 1, 11 respondents (10.8 per cent) strongly agreed that the relationship between the management staff and their subordinate is cordial, while 55 of them (51 per cent) agreed to the question. Five respondents (4.9 per cent) were undecided. On the other hand 20 of the remaining respondents (19.6 per cent) of the sampled disagreed and 11 of them (10.8 per cent) strongly disagreed. The indication of this study provides information that PCC and CCB have amiable relationships between the management staff and their subordinate. 
The bureaucratic nature of the institutions was also put into consideration, outcome of the field research showed that 38 respondents which represented (34.3 per cent) strongly agreed to the inquiry and twenty-eight ( 27.5 per cent) also agreed that the bureaucratic nature of the institutions affects the agencies efficiency and performance. In addition, 5 respondents (4.9 per cent) were undecided and the remaining 15 (14.7 per cent) and 16 (15.7) strongly disagreed and disagreed respectively. The information provided that in the selected institutions, i.e. PCC and CCB, administrative nature of the institutions affects their effectiveness in course of operation.

The data presented in the table also showed whether the mode of operation of the institution is effective. Out of 102 sampled respondents, 4 respondents (3.9 per cent) and 12 (11.8 per cent) strongly agreed and agreed respectively that the mode of operation of the institution is effective. However, 9 respondents represented by approximately ( 8.8 per cent) neither agreed nor disagreed to the question. They were undecided. Moreover, the bulk of the respondents 77 ( 75.5 per cent) cumulatively agreed and strongly disagreed that mode of operation of the institution is not effective. The implication of these findings is that the mode of operation of the institutions lack effectiveness and hamper the institutions performance.

The result of the field analysis from the table presented below showed that a sum of 61 respondents (56.8 per cent) strongly agreed, as well as agreed that overhauling the mode of operation in the institutions is required. Cumulative of thirty respondents are of the contrary opinion as they strongly disagreed and agreed. Eleven respondents were sitting on the fence, they remained undecided. The connotation of these findings is that there are traces of unethical behaviours in the institutions which resulted into calling for the revamping by the large numbers of the staff who incidentally are the respondents of this study.

This study seeks to know whether the structure allows free flow of information between superior and subordinate. Descriptive analysis of the study show that the structure does not allow free flow of information between superior and subordinate. Seventy-one (69.6 per cent) of the sampled population strongly disagreed that the structure allows free flow of information between superior and subordinate. Twenty-one respondents represented by 20.5 per cent agreed to the question. Only eight of the respondents were undecided and two respondents left the space blank. The insinuation of this study is that free flow of information between the superior and subordinate is not allowed in the institutions.

Transparency was said to be the watchword of this institutions, in the course of this study, efforts were made to know whether the structure of the organisation inhibits transparency and public accountability. The indication from the outcome of the field study showed that only fourteen (13.7 per cent) respondents cumulatively strongly agreed and agreed with regards to the transparency of the structure in the institutions. However, the bulk of the respondents, $69(67.6 \%)$ are of the contrary opinion. Seventeen of the respondents (16.6 per cent) were undecided and two respondents left the space blank. The consequence of this is that with the response of the bulk of the sampled respondents, one can conclude by saying that the structure of the organisation impedes transparency and public accountability.

Finally, the study also enquired whether the establishments of the institutions have assisted in improving the ethical and professional conduct of public servants in the country. The data presentation in the table below showed that 19 respondents which was represented by 18.6 per cent of the sampled population strongly agreed to the question that the establishment of the institution has really assisted in improving the ethical and professional conduct of public servants in the country. 22 respondents represented by 21.6 
per cent of the sampled population agreed to the question, while 6 respondents 5.9 per cent were undecided, 39 respondents (38.2 per cent) disagreed and 14 (13.7 per cent) of the respondents strongly disagreed. Two respondents left the space without picking any option. The inference of this study enables the researcher to know that the establishments of the institutions have indeed assisted and contributed toward improving the ethical and professional conduct of public servants in the country.

To verify the above data generated through questionnaire, interviews were conducted and to elicit further information on issues relating to the study which centres on the structure and mode of operation of the selected accountability institutions in Nigeria. Interviews were conducted with 35 respondents from the three Departments in PCC, eight committees in CCB, twenty public servants (active service or retired) and four officials of any ministry, department and agency. The awareness of the activities of the two institutions were first of all established especially while asking questions from staff of the institution other than which they were employed and also the civil servants outside the institutions under consideration. It was gathered that every respondents were aware of the activities of the two institutions. When asking questions relating to the structure and mode of operation of the selected accountability institutions in Nigeria, three questions were asked on how the respondents could describe the structures of the organisations. The officials in the director cadre of the three departments in Public Complaints Commission and the Chairmen or their representatives of the eight committees in Code of Conduct Bureau described the structure of the organisations as one that allows for cordial relationship between the management staff and other employees in the institutions. They went further that the organogram of the institutions allows for free flow of information and it was not limited to "top-bottom" approach; "bottom-top" approach was also encouraged according to the structure and mode of operation of the institutions. While probing further, it was revealed that the structure of the institutions, from the conception, took cognisance of the role played by bureaucratic nature of any organisation and its effect on performance. According to them, this has really helped the institutions in the discharge of their duties. All the information gotten from this interview has corroborated the data gotten from administration of questionnaire.

Just like the respondents of the questionnaire, the respondents of the interview also pick out lack of adherence to the mode of operation as a major impediment on performance of the two selected institutions. The civil servants, when asked the same question shared the similar point of view, but in addendum they raised the issue of politicisation of the structure, thereby jamming effectiveness and performance.

Table 1. Analyses of the Structure and Mode of Operation of the Selected Accountability Institutions in Nigeria

\begin{tabular}{lccc}
\hline & Frequency & Percent & Cumulative Percent \\
\hline \multicolumn{1}{c}{ Relationship between the management staff and their subordinate is cordial. } \\
\hline Strongly Disagree & 11 & 10.8 & 10.8 \\
Disagree & 20 & 19.6 & 30.4 \\
Undecided & 5 & 4.9 & 35.3 \\
Agree & 55 & 53.9 & 89.2 \\
Strongly Agree & 11 & 10.8 & $\mathbf{1 0 0 . 0}$ \\
\hline Total & $\mathbf{1 0 2}$ & $\mathbf{1 0 0 . 0}$
\end{tabular}

\begin{tabular}{lccc}
\multicolumn{4}{c}{ The bureaucratic nature of the institutions affects performance } \\
\hline Strongly Disagree & 15 & 14.7 & 14.7 \\
Disagree & 16 & 15.7 & 30.4
\end{tabular}




\begin{tabular}{lccc} 
Undecided & 5 & 4.9 & 35.3 \\
Agree & 28 & 27.5 & 62.8 \\
Strongly Agree & 38 & 37.3 & $\mathbf{1 0 0 . 0}$ \\
\hline Total & $\mathbf{1 0 2}$ & $\mathbf{1 0 0 . 0}$ & \\
& & \\
\hline \multicolumn{4}{c}{ The mode of operation of the institution is effective. } \\
\hline Strongly Disagree & 27 & 26.5 & 26.5 \\
Disagree & 50 & 49.0 & 75.5 \\
Undecided & 9 & 8.8 & 84.3 \\
Agree & 12 & 11.8 & 96.1 \\
Strongly Agree & 4 & 3.9 & $\mathbf{1 0 0 . 0}$ \\
\hline Total & $\mathbf{1 0 2}$ & $\mathbf{1 0 0 . 0}$ & \\
& & \\
\hline & & 7.8 & 7.8 \\
\hline Strongly Disagree & The mode of operation needs to be over-hauled. & 29.4 \\
Disagree & 8 & 21.6 & 40.2 \\
Undecided & 22 & 10.8 & 71.6 \\
Agree & 11 & 31.4 & $\mathbf{1 0 0 . 0}$ \\
Strongly Agree & 32 & 28.4 & \\
\hline Total & 29 & $\mathbf{1 0 0 . 0}$ &
\end{tabular}

Table 1b. Analyses of the Structure and Mode of Operation of the Selected Accountability Institutions in Nigeria

\begin{tabular}{lccc}
\hline & Frequency & Percent & Cumulative Percent \\
\hline \multicolumn{1}{c}{ The structure allows free flow of information between } & superior and subordinate. \\
Strongly Disagree & 23 & 22.5 & 22.5 \\
Disagree & 48 & 47.1 & 69.6 \\
Undecided & 10 & 9.8 & 79.4 \\
Agree & 18 & 17.6 & 97.0 \\
Strongly Agree & 3 & 2.9 & $\mathbf{1 0 0 . 0}$ \\
\hline Total & $\mathbf{1 0 2}$ & $\mathbf{1 0 0 . 0}$ &
\end{tabular}

\begin{tabular}{lccc}
\hline \multicolumn{4}{c}{ The structure of the organisation inhibits transparency and public accountability } \\
\hline Strongly Disagree & 29 & 28.4 & 28.4 \\
Disagree & 40 & 39.2 & 67.6 \\
Undecided & 19 & 18.6 & 86.2 \\
Agree & 10 & 9.8 & 96.0 \\
Strongly Agree & 4 & 3.9 & $\mathbf{1 0 0 . 0}$ \\
\hline Total & $\mathbf{1 0 2}$ & $\mathbf{1 0 0 . 0}$ & \\
& & \\
\hline Establishment of the institution has assisted in improving the ethical and professional \\
\hline Strongly Disagree & 14 & 13.7 & 13.7 \\
Disagree & 39 & 38.2 & 51.9 \\
Undecided & 8 & 7.8 & 59.7 \\
Agree & 22 & 21.6 & 81.3 \\
Strongly Agree & 19 & 18.6 & $\mathbf{1 0 0 . 0}$ \\
\hline Total & $\mathbf{1 0 2}$ & $\mathbf{1 0 0 . 0}$ &
\end{tabular}

\section{Hypothesis Testing}

Hypothesis formulated for the study was tested using appropriate statistical tools. The tests were carried out following the null hypothesis test method, this involved the statement of a 
negative propositions. The proposition is accepted or rejected following some statistical tests criteria.

The null hypothesis stated that:

The structure and mode of operation of the selected accountability institutions does not have significant effect on the activities and performance of the institutions

\section{Results of the Analysis and Discussions}

The relevant questions that were posed to test the hypothesis bear relevance of this hypothesis were seven in number which are presented in the table 1 . However, to test this hypothesis, simple standardized regression coefficient analysis was employed. Table 2 presented indicated the model summary of the simple regression equation that predicted significant effect of the structure and mode of operation of the selected agencies on the activities and performance of the institutions. The explanation of the values presented is given below.

To test the hypothesis, simple regression analysis was employed to examine the independent variable against dependent variable used in determining dependent variable. Table 2 indicates the model summary of the simple regression equation that predicted significant effect of the structure and mode of operation of the selected agencies and the institution activities and performance. The explanation of the values presented is given in the tables below.

The model summary table provides useful information about regression analysis. First, the 'simple $\mathrm{R}$ ' column is the correlation between the actually observed independent variable and the predicted dependent variable (i.e. predicted by the regression equation). ' $R$ square' is the square of $\mathrm{R}$ and is also known as the 'coefficient of determination'. It states the proportion (percentage) of the (sample) variable in the dependent variable that can be attributed to the independent variable(s). In this study 50\% of the variations in the institutions activities and performance could be accounted for by the structure and mode of operation of the selected agencies. The adjusted $\mathrm{R}$ square refers to the best estimate of $\mathrm{R}$ square for the population from which the sample was drawn. Finally, the 'standard error of estimate' indicates that, on average, observed interrelationships between management staff deviate from the predicted regression line by a score of .227 . This hypothesis which stated that "the structure and mode of operation of the selected institutions do not have significant effect on the activities and performance of the institutions was rejected at $\mathrm{R}=.504, \mathrm{R}^{2}=$ $.254, \mathrm{~F}(7,94)=4.568 ; \rho<.05$. This implies that the structure and mode of operation of the selected agencies have significance effect on the activities and performance of the institutions.

Analysis of this hypothesis helps the researcher to know the effect and influence of the mode and structure of the institutions under study, application of the Pearson Regression Analysis enable the investigator to know whether the structure and mode of operation of the selected agencies does not have significance effect on the activities and performance of the institutions. The outcome of this survey showed that the tested variables consider for this study show that the structure and mode of operation of the selected agencies does have significance effect on the activities and performance of the institutions. However, the significance effect is minor. 
Table 2. Model Summary of the Simple Regression for the Structure and Mode of Operation

\begin{tabular}{ccccc}
\hline \multicolumn{4}{c}{ Model Summary } \\
\hline Model & R & R Square & Adjusted R Square & Std. Error of the Estimate \\
\hline 1 & $.504^{\mathrm{a}}$ & .254 & .198 & .227 \\
\hline a. Predictors: (Constant), QB7, QB3, QB5, QB2, QB6, QB4, QB1
\end{tabular}

Table 3. Summary of Analysis of Variance for the Structure and Mode of Operation and Performance of the Institutions

\begin{tabular}{ccccccc}
\hline \multicolumn{7}{c}{ ANOVA $^{\mathbf{b}}$} \\
\hline Model & Sum of Squares & Df & Mean Square & F & Sig. \\
\hline \multirow{2}{*}{1} & Regression & 1.655 & 7 & .236 & 4.568 & $.000^{\mathrm{a}}$ \\
& Residual & 4.865 & 94 & .052 & & \\
\cline { 2 - 7 } & Total & 6.520 & 101 & & & \\
\hline
\end{tabular}

a. Predictors: (Constant), QB7, QB3, QB5, QB2, QB6, QB4, QB1

b. Dependent Variable: Institutions

\section{CONCLUSION}

The study concluded that the structure and mode of operation of Public Complaints Commission and Code of Conduct Bureau have significant effect on the activities and performance of the institutions, consequently the activities and performance of the institutions have momentous corollary on governance in the period under study in Nigeria, although, the effect is minimal, hence, a fundamental restructuring is required.

\section{REFERENCES}

Adegbite, E. O. (2009). Accounting, Accountability and National Development. Compass December 16, 33-34

Appah, E. \& Appiah, K. Z. A. (2010). Fraud and Development of Sound Financial Institutions in Nigeria, Nigerian Journal for Development Research, 1(1): 49 - 56.

Asaolu, T. O., Oyesanmi, O. A., Oladele, P. O. \& Oladoyin, A. M. (2005). Privatisation and Commercialization in Nigeria: Implication and Prospects for Good Governance. South African Journal of Business Management Graduate School of Business, University of Stellenbosch, South Africa, Vol. 36, No. 3, September, p 65-74

Awopeju, A. \& Oyewole, A. (2011). An Assessment of the Cases of Ombudsman (PCC) as a Tool of Accountability in Ondo State, Nigeria. Journal of Sustainable Development in Africa. Vol. 13. No. 4

Bello, S. (2001). Fraud Prevention and Control in Nigerian Public Service: The need for a Dimensional Approach, Journal of Business Administration, 1(2): 118-133.

Bovens, M. (2005) A Framework for the Anaysis and Assessment of Accountability Arrangements in the Public Domain. In E. Ferlie, L. Lynne \& C. Pollitt (eds.), The Oxford Handbook of Public Management, Oxford: Oxford University Press

Bovens, M. (2005). Public Accountability. In Ferlie, Ewan. Laurence E. Lynn Jr. \& Christopher Pollit (eds). The Oxford Handbook of Public Management. Oxford: Oxford University Press.

Code of Conduct Bureau (2013). Code of Conduct for Public Officers: Tips for Monitoring, Abuja: Code of Conduct Bureau

Doyal, L. \& Gough, I. (1991) A Theory of Human Need. Macmillian

Federal Republic of Nigeria (1999). Constitution of the Federal Republic of Nigeria 
Fisher, E. (2004) The European Union in the Age of Accountability. Oxford Journal of Legal Studies, 24, 1:495-515

http://www.international/policybrief.org/conferences/ibadan-conference-2012/39effectiveness-of-public-complaints-commission-on-labour-force-a-case-study-ofnigeria-public-complaints-commission

Ibietan, J. (2012). Corruption and Public Accountability in the Nigerian Public Sector: Interogating the Omission. European Journal of Business Management Vol. 5, No. 15, 263-286

Idemudia, R.U. P. (2008). Strategies for Promotion of Transparency and Accountability in Political Governance in Africa: An Assessment of Nigerian Experience International Journal of Communication, UNN. 8, 502-519

Ifesinachi, K. ( 2004). Africa's Wind of Corruption: Whether Anti-Corruption Policies, Nigerian Journal of Public Administration and Local Government, UNN. XII(1) (May) $75-86$

Kabouoh, M. \& Oyedokun P. (2012). Effectiveness of Public Complaints Commission on Labour Force: A Case Study of Nigeria Public Complaints Commission. International Institute for Policy Review and Development Strategies

Kolade, C. (2001) Corruption in Africa: Causes, Effects and Counter-Measures," in Belshaw, D, Calderisi, R; and Sugden, C. (eds). Faith in Development . Oxford: Regnum Books International.79-87

March, J. G. \& Olson, J. P. (1995) Democratic Governance. New York: The Free Press

Mulgan, R. (2003) Holding Power to Account: Accountability in Modern Democracies. New York: Basingstoke, Palgrave

Ogbuke, M. U. \& Enojo, K. E (2007) Corruption in Nigeria: Implications for Urban Development, in Nigerian Journal of Research and Production, ESUT Enugu. 11( 1) (November), 60-74

Ojiakor, N. (2009). Nigerian Socio-political Development: Issues and Problems, Enugu: John

Ola R, O. F. \& Effiong, O. J. (1999) Public Financial Management in Nigeria. Lagos: Amfitop Books p. 224-229

Olowu, D. (2002) Accountability and Transparency. In Adamolekun L. (ed) Public Administration in Africa: Main Issues and Selected Country Studies. Ibadan: Spectrum Books Limited. 139-158

Onwuka, C. C. Okoh, C. I. \& Eme O. I. (2009) Corruption in Nigeria: Nature, Forms and Challenges before Anti-Corruption Agencies. Interdisciplinary Journal of Contemporary Research in Business. 1(8) 114-132

Premchand, A. (1999) Public Financial Management in Schviavo-Campo S. (ed) Governance Corruption and Public Financial Management. Asian Development Bank. Manila, Philippines. www.adb.org

Przeworski, A., Stokes, S. C. \& Manin, B. (eds) (1999) Democracy, Accountability and Representation. Cambridge: Cambridge University Press

Public Complaints Commission (2012) Annual Report Abuja. Fix Impressions Ltd.

Staftan (2009) Accountability: The Core Concept and Its Subtypes, London: African Power and Politics Programme (APPP) Retrieved from www.odi.org.uk on 23/06/15

Sutcliffe (2002) Public Fund Digest. International Federation of Accountants (IFAC) www.ifac.org

The Institute of Internal Auditors (2011) Supplemental Guidance: Public Sector Definition USA 